\title{
CONSTRUCTIVE SOLUTION OF HIGHLY EFFECTIVE PHOTOENERGY MODULE: DEVELOPMENT AND EXPERIMENTAL TESTING
}

\begin{abstract}
Based on experimental study and computer modeling of working temperature influence on the efficiency of Chinese production silicon solar cells identified temperature dependence of efficiency shows the feasibility of using Chinese production Si-SC in the construction of photovoltaic thermal system, which together with the heat pump is part of a combined system for hot water supply, heating and air conditioning. Based on a detailed analysis of the working temperature influence on the efficiency of photovoltaic processes that determine the solar cells work, it has been developed the optimal construction and technological solution of hybrid solar generated module, the main feature of which is the heat exchange block, designed to reduce the solar cells working temperature. The experimental testing of hybrid modules samples equipped with developed cooling system, high-voltage part of power take-off system demonstrates their reliability and high efficiency which allow to achieve the such module efficiency up to $\mathbf{1 8 . 5} \%$. References 19 , tables 1 , figures 8 .

Keywords: silicon solar cells, working temperature, efficiency dependence, diode and output parameters, cooling system, solar irradiation concentration, hybrid solar generating module.
\end{abstract}

На основе экспериментального исследования в комплексе с компьютерным моделированием влияния рабочей температуры на эффективность кремниевых солнечных элементов китайского производства выявлена температурная зависимость их эффективности. Температурная зависимость показывает целесообразность использования солнечных элементов китайского производства в составе фотоэлектрической тепловой системы, которая вместе с тепловым насосом является частью комбинированной системы горячего водоснабжения, отопления и кондициониования воздуха. На основе детального анализа влияния рабочей температуры на эффективность фотоэлектрических процессов, определяющих работу солнечных элементов, было разработано оптимальное конструктивно-технологическое рещение гибридного солнечного генерирующего модуля, основной особенностью которого является теплообменный блок, предназначен для снижения рабочей температуры солнечных элементов. Экспериментальные испытания образцов таких модулей, оснащенных разработанной системой охлаждения и высоковольтной системой отбора мощности, демонстрируют их надежность и высокую эффективность, позволяющие достичь КПД гибридного модуля до 18,5 \%. Библ. 19, табл. 1, рис. 8.

Ключевые слова: кремниевые солнечные элементы, рабочая температура, зависимость эффективности, диодные и выходные параметры, система охлаждения, концентрация солнечного излучения, гибридный солнечный модуль.

Introduction. Now by increasing the efficiency of industrial production monocrystalline silicon solar cells (Si-SC) up to $17-18 \%$ while significantly reducing their cost Chinese manufacturers were the largest exporters of photovoltaic products in the world [1]. A significant part of the manufacturers engaged in industrial production of solar modules, using Chinese-made solar cells. In addition, the largest segment of the market of imported solar modules also is occupied by Chinese manufacturers. For selling solar cells Chinese manufacturers in addition to efficiency and output parameters indicate the open circuit voltage $\left(U_{o c}\right)$, shortcircuit current density $\left(J_{s c}\right)$, the fill factor $(F F)$ of the illuminated current-voltage characteristic (CVC) which are measured at room temperature $25^{\circ} \mathrm{C}$.

However, during Si-SC working, according to the efficiency value only a small part of solar energy using to generate electricity. The majority of solar radiation has converted to heat in the device structure. This leads to an increase of Si-SC working temperature, which reduces their efficiency. In a significant amount of research works have been analyzed the influence of temperature on the efficiency of monocrystalline Si-SC, which are produced in European countries and Russia (see, [2-4]). Thus, established physical mechanisms lead to lower efficiency. At the same time, similar studies of Chinese production $\mathrm{Si}-\mathrm{SC}$ with a few exceptions was not carried out [5]. Now a popular option for increasing a power of solar energy stations is the equipment of solar generating module (SGM) by low solar concentration system. Using low- concentration of solar radiation is economically justified. The equipment of photovoltaic modules, by concentrators single or double-sided flat focline type, as shown in Fig. 1, with the degree of concentration up to 2 , which is optimal for solar cells of conventional design based on single-crystal silicon allows to twice reduce the number of used solar cells, thereby reducing consumption of semiconductor material.

However, preliminary calculations of thermal parameters for SGM equipped with concentrator show that without cooling systems such using lowconcentration solar radiation increases the SGM equilibrium temperature up to $55{ }^{\circ} \mathrm{C}$, close to the maximum operating temperature of the Si-SC.

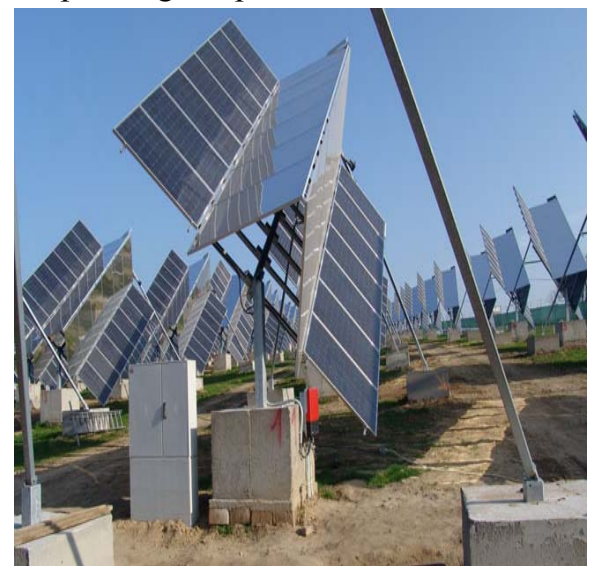

Fig. 1. Example of SGM module, equipped with a one-sided low solar concentration system

(C) R.V. Zaitsev, M.V. Kirichenko, G.S. Khrypunov, L.V. Zaitseva, O.N. Chugai, A.A. Drozdova 
Thus, the study of temperature influence on the efficiency of photovoltaic processes in industrial samples of Chinese production Si-SC should be consider as relevant research objective, which has great practical importance. In the first phase were carried out, the experimental study the effect of temperature on the output diode parameters of industrial samples Chinese production Si-SC.

In the second stage, we analyze the physical mechanisms of the temperature effect on the output and diode parameters industrial samples of investigated Si-SC. Based on the experimental data obtained in the third step was the development of a hybrid solar generating module concept.

Aim of the investigation development of highly effective photoenergy module based on silicon solar cells construction solution and their experimental testing.

1. Experimental technique. According to the equivalent Si-SC circuit quantitative characteristics of photovoltaic processes that occur in such device structures are diode characteristics: density of the photocurrent $\left(J_{p h}\right)$, the diode saturation current density $\left(J_{o}\right)$, the coefficient of diode ideality $(A)$, series resistance $\left(R_{s}\right)$ and shunt resistance $\left(R_{s h}\right)$, calculated per unit area of SC.

By the analyzing the literature [6], it can be shown that with increasing $J_{f}, R_{s h}$, and with decreasing $J_{o}, A, R_{s}$ increases the efficiency of solar cells. The photocurrent density, which quantifies the effectiveness of nonequilibrium charge carriers generation and diffusion processes, determined by the number of photons arriving to the base layer, a quantum yield of the photoelectric effect and the of nonequilibrium charge carriers lifetime in the base layer. The values of the ideality coefficient and density of diode saturation current, which quantitatively characterize the efficiency of the of nonequilibrium charge carriers separation in $\mathrm{Si}-\mathrm{SC}$, controlled by the recombination speed in the space charge area and the energy structure of the separation barrier. Shunt resistance is included in the equivalent circuit of solar cells in order to take into account the influence on the efficiency photovoltaic processes of low resistivity local parts of the device structure and the end surfaces. The series resistance of solar cells, the amount of which determines the nonequilibrium charge carriers collection efficiency depends on the electrical conductivity of the base Si-SC layer, the contact resistance and the recombination speed of nonequilibrium charge carriers on the back and front contacts.

In this work calculation of output and diode parameters for investigated SC was carried out using the developed analytical processing program based on an approximation of the experimental illuminated $\mathrm{CVC}$ by the theoretical expression from [6]. Illuminated CVC Si-SC measured by the loaded method during Illumination SC by the solar radiation simulator for terrestrial conditions with the light power up to $100 \mathrm{~mW} / \mathrm{cm}^{2}$. Measuring scheme, which has shown in Fig. 2,a, as a source of simulating solar radiation includes LED Illuminator (Fig. 2,b) with microcontroller control.

The variable load resistance having six decades with the corresponding resistance values, which allows precisely vary value when measuring the CVC in the range from 0.01 up to $1000 \mathrm{Ohm}$. Registering of voltage value on load resistance has carried out by digital multimeter Mastech MS8226 DMM. Initial registering and control during measurements the value of radiation power on the SC front surface, were performed using standard Si-SC having a known value of the short-circuit current, and place it near the investigated Si-SC. By changing, the distance between the Si-SC and LED illuminator emitting element achieved the compliance with the actual value of $I_{s c}$ for standard Si-SC to its value at $100 \mathrm{~mW} / \mathrm{cm}^{2}$ irradiance power, after that investigated $\mathrm{Si}-\mathrm{SC}$ has been connected to the measuring circuit.

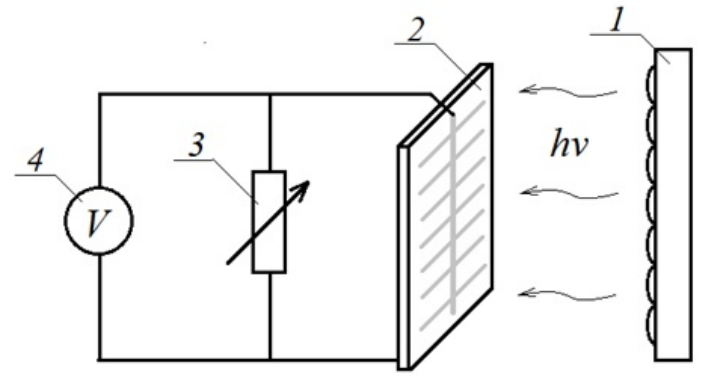

$a$

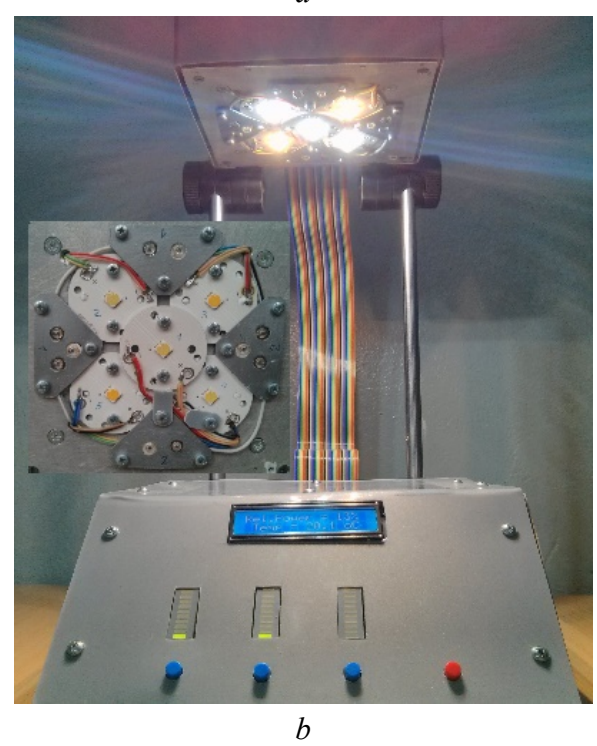

Fig. 2. Measuring scheme for investigated loaded currentvoltage characteristics $(a)$ and the appearance of the LED illuminator $(b)$, the inset shows the location of the LEDs on the radiating element

( 1 - LED Illuminator; 2 - investigated Si-SC; 3 - variable load resistance; 4 -multimeter to measure the voltage on the load resistance)

3. Results and its discussion. For the experimental studies of the temperature effect on the output and diode parameters of Si-SC were selected monocrystalline Chinese production $\mathrm{Si}-\mathrm{SC}$ with the characteristic values of efficiency, which represent the minimum, maximum and average values for the device structures on the market.

For this samples at temperatures from $0{ }^{\circ} \mathrm{C}$ up to $50{ }^{\circ} \mathrm{C}$ illuminated CVC were measured. As a result of subsequent analytical processing measured illuminated CVC were determined output and diode parameters investigated Si-SC. 
The analysis shows that with increasing temperature, observed practically linear decrease of efficiency (Fig. 3, on this and other figures $1,2,3$ is the numbers of investigated SC).

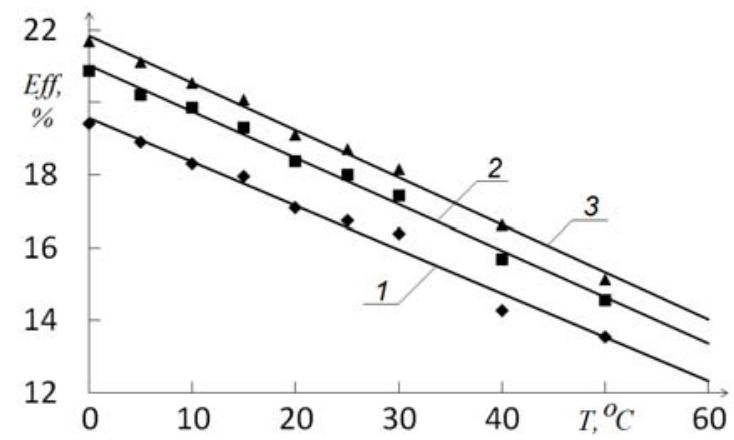

Fig. 3. Effect of working temperature on the Si-SC efficiency

The reduction factor, which describes the relative change of efficiency when the temperature changes by one degree, is $0.7 \% /{ }^{\circ} \mathrm{C}$. For the open-circuit voltage and short circuit current density also observed reduce their values with increasing operating temperature (Fig. 4,a,b). Fill factor of the illuminated CVC does not change substantially with increasing temperature.
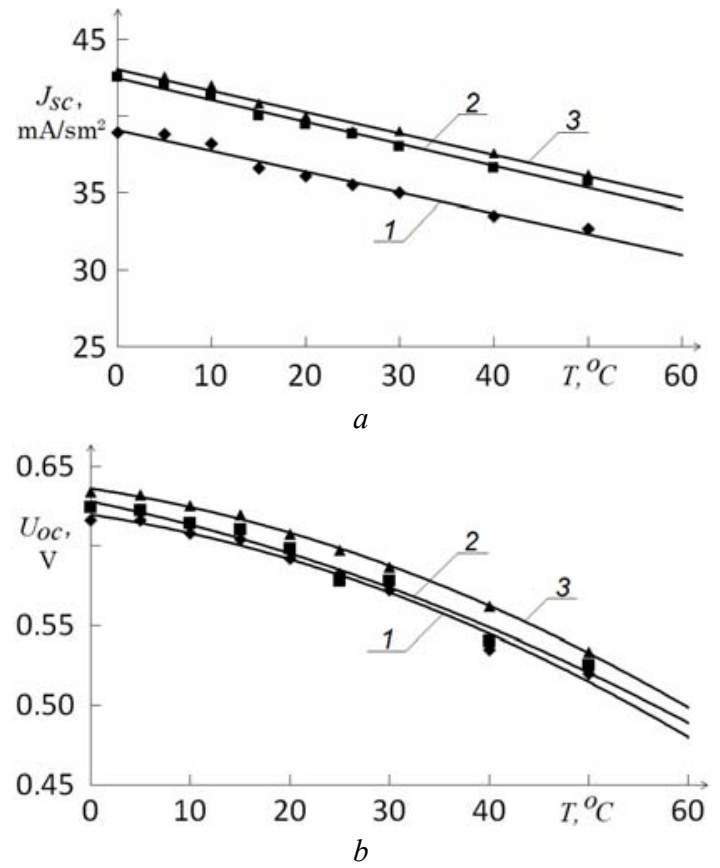

Fig. 4. Effect of working temperature on the Si-SC short circuit current density $(a)$ and the open circuit voltage $(b)$

Analysis of the diode parameters showed that the recorded decrease of efficiency due to the increase of the diode saturation current density (Fig. 5,a) and a decrease of shunt resistance (Fig. 5,b).

The analysis of the physical mechanisms of the temperature effect on the output and diode parameters for Chinese production Si-SC industrial samples shown that experimental results are only partially can be commented upon in the framework of traditional ideas about the influence of temperature on the efficiency of photovoltaic processes in the Si-SC, which has described in [7]. According to traditional views, which correspond to the experimental studies of $\mathrm{Si}-\mathrm{SC}$ at increasing the temperature the diffusion length of the nonequilibrium carriers in $\mathrm{Si}$ increases. This is because the diffusion coefficient is not changed or increased, and the minority carrier lifetime increases with increasing temperature. The increase of minority carriers diffusion length leads to an increase of short circuit current density with increasing temperature. However, this effect is small and its value on level $0.07 \% /{ }^{\circ} \mathrm{C}$. Reduction of the open circuit voltage significantly exceeds the increase of short circuit current density and its value is up to $0.4 \% /{ }^{\circ} \mathrm{C}$. Smoother shape of illuminated $\mathrm{CVC}$ at higher temperatures leads to reduce the fill factor of illuminated CVC. Overall, therefore, increase of temperature leads to a relative decrease of the efficiency on level of $0.5 \% /{ }^{\circ} \mathrm{C}$.
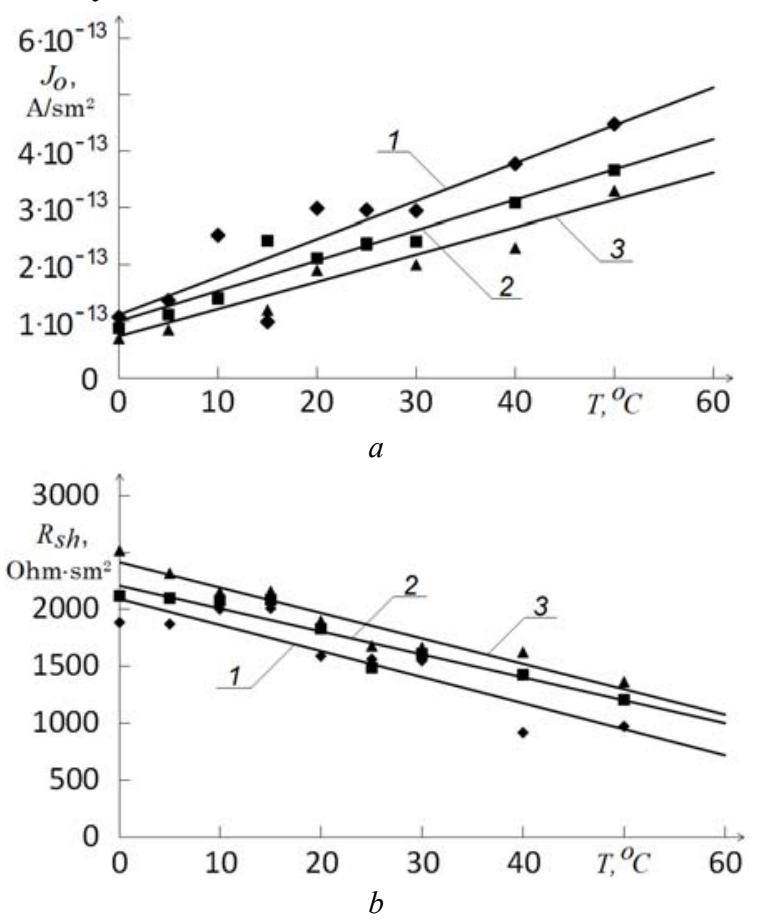

Fig. 5. Effect of working temperature on the density of diode saturation current $(a)$ and shunt resistance $(b)$

According to the experimental data practically for Chinese-made solar cells relative efficiency reduction higher and its value is at $0.7 \% /{ }^{\circ} \mathrm{C}$. At this the shortcircuit current density decreases, and the fill factor of illuminated CVC practically unchanged.

According to the existing physical representations the density of the diode saturation current is the most important diode parameter, which effect on changes of SC output parameters with changes the working temperature. The exponential increase of diode saturation current density evidence that basic physical mechanism of $J_{o}$ increase is thermally activated growth of the charge carrier's concentration. Since experimental dependence $J_{o}(T)$ is not a linearized in $\ln J_{o}-1000 / T$ coordinates, the mechanism is not only one, above mentioned. On its existence indicates the experimentally established unconventional decline of short-circuit current density with increasing of working temperature.

Analysis of diode parameters shows that the abnormally high efficiency reduction and non-traditional decrease of short-circuit current density due to experimentally registered decrease of shunt resistance. 
Current in high conductivity areas reduce the contribution of the photocurrent in the short-circuit current and this current is additional physical mechanism that reduces efficiency.

Development of a hybrid photovoltaic module concept carried out based on experimentally established data about high speed of efficiency reduction for China production Si-SC. This fact reduces their relatively high initial output parameters and determines the feasibility of using them as a part of the hybrid solar generating module (HSGM), which is a hybrid of solar cells and solar thermal collector and allows to ensure cooling of the silicon device structure due to coolant circulation. Depending on the necessary technological requirements worked out three basic modes of HSGM working [8]: ensuring the most efficient power generation, ensuring maximum efficiency of thermal energy and maximizing the overall efficiency. In [9] developed designs that for maximize the electric power ensure the heat extraction from SC front surface to the environment and from the rear surface to the coolant circuit. The main feature of the module design that meets this working regime is the absence of air layer between the solar cells and translucent coating. With this working regime, the coolant temperature in the circuit must be less than $35{ }^{\circ} \mathrm{C}$. However, since fluid heated by module has a low temperature, it is required that a further heating, which leads to the need for additional hardware. For example, this HSGM working regime enables combined system for hot water supply, heating and air conditioning based on heat pump and HSGM [10].

In this paper, for cooling Chinese production Si-SC we propose a simple and reliable design of a hybrid solar generated module. To realize the cooling system via a compound with heat conductivity $(1.04-1.44) \mathrm{W} /(\mathrm{m} \cdot \mathrm{K})$ is assumed to provide a thermal contact between the back surface of the solar module and aluminum absorber to which are welded aluminum tubes through which water flows.

We propose to gluing by this compound plate aluminum absorber with welded tubes directly to the back surface of the solar module (see Fig. 6).

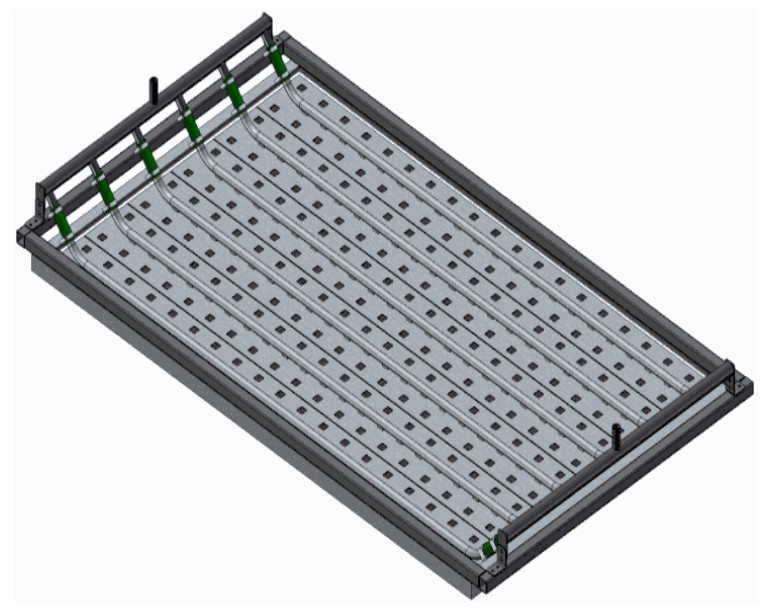

Fig. 6. General view of HSGM module, equipped with a cooling system on the back side

Temperature changes were calculated in the layers included in the standard solar module design (see Fig. 7).

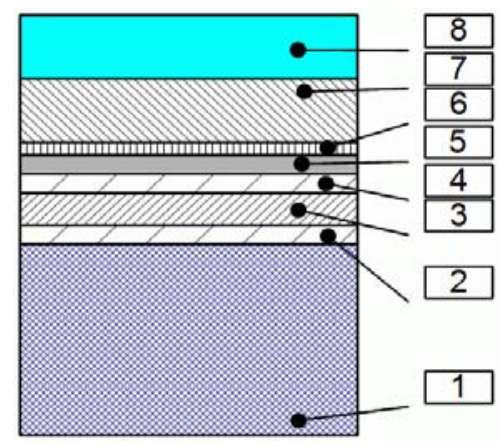

Fig. 7. Construction of hybrid solar generated module:

1 - glass; 2, 4 -EVA film for laminating; 3 - silicon SC;

5 - protective PVC layer; 6 - heat conductive compound;

7 - aluminium absorber; 8 - coolant (water)

In calculating we the expected natural air cooling from front surface and cooling of back surface with the coolant. Area of SC with size $158 \mathrm{~mm} \times 158 \mathrm{~mm}$ was $0.02496 \mathrm{~m}^{2}$, thermal energy, absorbing by SC taking into account the conversion of solar energy into electrical energy is $24.96 \mathrm{~W} / \mathrm{m}^{2}$. Thermal resistances $R_{t}(\mathrm{~K} / \mathrm{W})$ and temperature changes $\Delta T(\mathrm{~K})$ on the layers that make up the construction solar module were calculated [11, 12]. Results are presented in Table 1.

Table 1

Calculated values of heat resistance $R_{t}(\mathrm{~K} / \mathrm{W})$ and temperature differences $\Delta T(\mathrm{~K})$ on layers that make up a construction of hybrid solar generated module

\begin{tabular}{|l|c|c|c|c|}
\hline \multicolumn{1}{|c|}{ Layers } & $\begin{array}{c}\text { Thickness } \\
\Delta, \mu \mathrm{m}\end{array}$ & $\begin{array}{c}\text { Heat conduction } \\
\text { coefficient, } \\
\mathrm{W} /(\mathrm{m} \cdot \mathrm{K})\end{array}$ & $\begin{array}{c}R_{t}, \\
\mathrm{~K} / \mathrm{W}\end{array}$ & $\begin{array}{c}\Delta T, \\
\mathrm{~K}\end{array}$ \\
\hline Glass & 4 & 1.15 & 0.1390 & -3.48 \\
\hline EVA & 0.5 & 0.33 & 0.0161 & -1.52 \\
\hline Si-SC & 0.15 & 150 & 0 & 0 \\
\hline PVC & 0.5 & 0.33 & 0.0110 & -1.52 \\
\hline EVA & 0.5 & 0.19 & 0.1050 & -2.63 \\
\hline Compound & 0.25 & 1.28 & 0.0080 & -0.20 \\
\hline Al absorber & 2 & 236 & $3.4 \cdot 10^{-4}$ & -0.01 \\
\hline
\end{tabular}

For minimize expends of generated electrical energy to coolant circulation, we proposed to use a thermosiphon system with slight overheating $(5-7)^{\circ}$ against to the environment. Then, taking into account the calculated temperature differences in the layers of the solar module its overheating against to the environment is reduced up to a (10-12) ${ }^{\circ} \mathrm{C}$, which reduces the efficiency losses from heat more than twice.

Based on the analysis of Table 1, the highest thermal resistance after the obligatory top glass has a protective PVC film. Changing it to a thin PET (polyethylene terephthalate or polyester), which is produced in thickness (20-150) $\mu \mathrm{m}$ and is close to the PVC value of the thermal conductivity $\kappa=0.24 \mathrm{~W} /(\mathrm{m} \cdot \mathrm{K})$ will reduce the $\Delta T$ in the protective layer up to $(0.2-0.4){ }^{\circ} \mathrm{K}$. It is also possible to reduce the EVA layer thickness from $0.5 \mathrm{~mm}$ to $0.3 \mathrm{~mm}$, which will reduce $\Delta T$ in this layer up to $0.9^{\circ} \mathrm{K}$. As a result of measures to reduce the system thermal resistance we can achieve the excess of SC temperature above water temperature less $1.5^{\circ} \mathrm{C}$.

In addition to the heat exchange units which fixed directly on the HSGM, cooling system also includes the supply and offtake coolant collectors, radiator which cools the coolant, expansion tank and connecting hoses [12-14]. 
Collectors are used to organize the coolant flow and carried out the distribution of uniform coolant flow from the radiator into the six flows in the number of heat exchange blocks and reverse association coolant flow at the outlet of heat exchanging blocks for supplying the radiator. Collectors are made from standard water pipes. Joining the collectors (Fig. 6) with a heat exchange block to prevent galvanic corrosion and thermal stress compensation is performed through the adapter in the form of segments of reinforced PVC hose. Cooling of the coolant, in which can be used as water or ethylene glycol aqueous solution, is carried out by passing it through the radiator of the tubular structure, made of steel tubing. Tubular radiator design simplifies manufacturing and provides sufficient heat dissipation area for effective heat dissipation extracted from cooled HSGM [15].

Since the cooling circuit is closed, at change the temperature changes the volume of fluid and to compensate for changes in the volumes it is necessary to use expansion tanks. The proposed cooling system can use standard diaphragm expansion tanks, designed for heating systems with solar collectors. They have a working pressure of $6 \mathrm{~atm}$, maximum up to $10 \mathrm{~atm}$, the maximum flow temperature $70{ }^{\circ} \mathrm{C}$, volume (33-40) 1 and equipped with the necessary fastening elements [16-18].

The experimental testing of the developed HSGM constructive solution carried out by field testing during the week by using generating stand consist from two HSGM samples, equipped according to the developed constructive solution and using a high-voltage power take-off system.

The experimental dependence of generated power distribution during the day is shown on Fig. 8. The analysis of this dependence makes it possible to conclude that the results of the calculation the optimal values of HSGM vertical installation angle allowed to achieve the character of power, generated by HSGM dependence which corresponds to the position of the Sun on the sky.

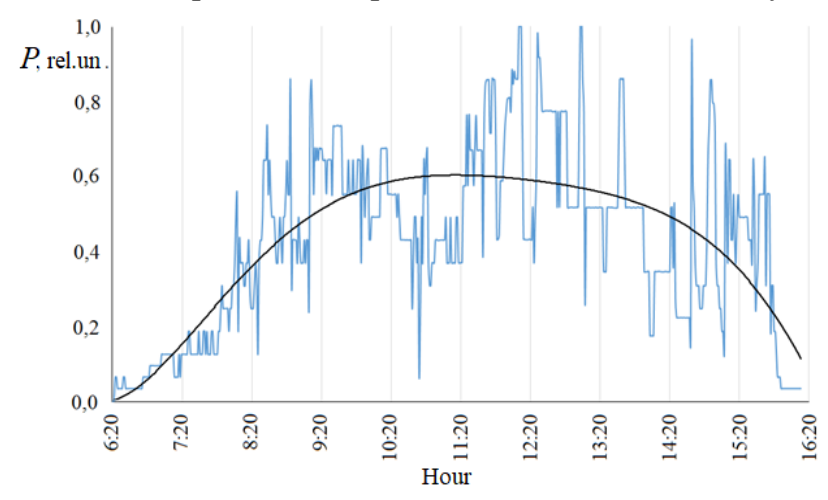

Fig. 8. Distribution of relative power generated by HSGM depending on daytime

During the tests, the working of HSGM cooling system, high-voltage part of power take-off system and the accuracy of HSGM installation angles were checked. The HSGM cooling system, built on the principle of coolant thermosiphon circulation, has been showed high efficiency - depending on the intensity of the incident solar radiation and the ambient temperature, the module temperature does not exceed $20-25^{\circ} \mathrm{C}$. Due to the design features, the cooling system operates completely autonomously, and coolant circulation is only ensured when HSGM photoreceiving surface is actually heated. The absence of temperature sensors and circulation pumps increases its reliability and minimizes energy needed for its working.

Concentrators of sunlight, made in the form of flat mirrors and installed on HSGM, have shown their resistance to wind and rain. The implemented angle of concentrators installation provides an effective selfcleaning from rain drops, while washing away the dust.

High-voltage DC-DC power take-off system [19] demonstrates their high reliability during testing.

In general, the implementation of the developed HSGM design solution allowed to achieve the efficiency this modules up to $18.5 \%$.

\section{Conclusions.}

The study of working temperature influence on the efficiency of Chinese production silicon solar cells shows that the reduction of efficiency is $0,07 \% /{ }^{\circ} \mathrm{C}$ when working temperature increases, that is significantly higher than in the device structures of European and Russian production and a due to the unconventional decrease of short circuit current density.

By the computer modeling of the quantitative influence of diode parameters on efficiency, it has been shown that Chinese production Si-SC efficiency decrease is due to not only by the growth of the traditional diode saturation current density, but also a decrease of shunt resistance.

Identified temperature dependence of efficiency shows the feasibility of using Chinese production Si-SC in the construction of photovoltaic thermal system, which together with the heat pump is part of a combined system for hot water supply, heating and air conditioning. Based on a detailed analysis of the working temperature influence on the efficiency of photovoltaic processes that determine the solar cells work, it was proposed the optimal construction and technological solution hybrid solar generated module, the main feature of which is the heat exchange block, designed to reduce the HSGM working temperature.

The experimental testing of HSGM samples with developed cooling system, high-voltage part of power take-off system demonstrates their reliability and high efficiency which allow to achieve the HSGM efficiency up to $18.5 \%$.

\section{REFERENCES}

1. Bye G., Ceccaroli B. Solar grade silicon: Technology status and industrial trends. Solar Energy Materials and Solar Cells, 2014, vol.130, pp. 634-646. doi: 10.1016/j.solmat.2014.06.019.

2. Singh P., Ravindra N.M. Temperature dependence of solar cell performance - an analysis. Solar Energy Materials and Solar Cells, 2012, vol.101, pp. 36-45. doi: 10.1016/j.solmat.2012.02.019.

3. Singh P., Singh S.N., Lal. M., Husain M. Temperature dependence of $\mathrm{I}-\mathrm{V}$ characteristics and performance parameters of silicon solar cell. Solar Energy Materials and Solar Cells, 2008, vol.92, iss.12, pp. 1611-1616. doi: 10.1016/j.solmat.2008.07.010.

4. Radziemska E. Effect of temperature on dark current characteristics of silicon solar cells and diodes. International 
Journal Energy Res, 2006, vol.30, iss.2, pp. 127-134. doi: 10.1002/er.1113.

5. Cai W., Chao F., JinLong T., DeXiong L., SiFu H., ZhiGang $\mathrm{X}$. The influence of environment temperatures on single crystalline and polycrystalline silicon solar cell performance. Science China: Physics, Mechanics and Astronomy, 2012, vol.55, no.2, pp. 235-241. doi: 10.1007/s11433-011-4619-z.

6. Möller H.J. Semiconductors for solar cells. Boston, Artech House, 1993.

7. Afanasyev V.P., Terukov E.I., Scherchenko A.A. Thin film solar cells on the silicon base. SPbSETU, LETI, 2012.

8. Kharchenko V.V., Nikitin B.A., Tichonov P.V. Select of photoenergy heat module parameters. Renewable and small energy 2012: Proc. of IX In-tern. ann. conf. M., 2012, pp. 292-297.

9. Ramos A., Chatzopoulou M.A., Guarracino I., Freeman J., Markides C.N. Hybrid photovoltaic-thermal solar systems for combined heating, cooling and power provision in the urban environment. Energy Conversion and Management, 2017, vol.150, pp. 838-850. doi: 10.1016/j.enconman.2017.03.024.

10. Zhang X., Zhao X., Smith S., Xu J., Yu X. Review of R\&D progress and practical application of the solar. Renewable Sustainable Energy Rev, 2012, vol.16, iss.1, pp. 599-617. doi: 10.1016/j.rser.2011.08.026.

11. Herrando M., Markides C.N. Hybrid PV and solar-thermal systems for domestic heat and power provision in the UK: Techno-economic considerations. Applied Energy, 2016, vol.161, pp.512-532. doi: 10.1016/j.apenergy.2015.09.025.

12. Dupeyrat P., Menezo C., Fortuin S. Study of the thermal and electrical performances of PVT solar hot water system. Energy and Buildings, 2014, vol.68, part C, pp.751-755. doi: 10.1016/j.enbuild.2012.09.032.

13. Zhao X., Zhang X. Handbook Nearly Zero Energy Building Refurbishment, Springer, 2013.

14. Romero Rodríguez L., Salmerón Lissén J.M., Sánchez Ramos J., Rodríguez Jara E.Á., Álvarez Domínguez S. Analysis of the economic feasibility and reduction of a building's energy consumption and emissions when integrating hybrid solar thermal/PV/micro-CHP systems. Applied Energy, 2016, vol.165, pp.828-838. doi: 10.1016/j.apenergy.2015.12.080.
15. He W., Chow T.-T., Ji J., Lu J., Pei G., Chan L. Hybrid photovoltaic and thermal solar-collector designed for natural circulation of water. Applied Energy, 2006, vol.83, iss.3, pp.199-210. doi: 10.1016/j.apenergy.2005.02.007.

16. Coventry J.S. Performance of a concentrating photovoltaic/thermal solar collector. Solar Energy, 2005, vol.78, iss.2, pp. 211-222. doi: 10.1016/j.solener.2004.03.014.

17. Pathak M.J.M., Sanders P.G., Pearce J.M. Optimizing limited solar roof access by exergy analysis of solar thermal, photovoltaic, and hybrid photovoltaic thermal systems. Applied Energy, 2014, vol.120, pp.115-124. doi: 10.1016/j.apenergy.2014.01.041.

18. Liang R., Zhang J., Ma L., Li Y. Performance evaluation of new type hybrid photovoltaic/thermal solar collector by experimental study. Applied Thermal Engineering, 2015, vol.75, pp.487-492. doi: 10.1016/j.applthermaleng.2014.09.075.

19. Zaitsev R.V., Kyrychenko M.V., Kholod A.V., Zaitseva L.V., Prokopenko D.S., Khrypunov G.S. Calculation of operating parameters of high-voltage power take-off system for the photovoltaic facility. Electrical engineering \& electromechanics, 2016, no.4, pp. 63-68. doi: 10.20998/2074272X.2016.4.09.

Received 14.09.2019

R.V. Zaitsev ${ }^{1}$, Doctor of Technical Science, Associate Professor, M.V. Kirichenko ${ }^{1}$, Candidate of Technical Science, Senior Researcher,

G.S. Khrypunov ${ }^{1}$, Doctor of Technical Science, Professor,

L.V. Zaitseva ${ }^{2}$, Candidate of Technical Science, Senior Lecturer, O.N. Chugai ${ }^{2}$, Doctor of Technical Science, Professor,

A.A. Drozdova ${ }^{1}$, Candidate of Phys.-Math. Science, Associate

Professor,

${ }^{1}$ National Technical University «Kharkiv Polytechnic Institute», 2, Kyrpychova Str., Kharkiv, 61002, Ukraine,

e-mail: zaitsev.poman@gmail.com

${ }^{2}$ Zhukovsky National Aerospace University «Kharkiv Aviation Institute»,

17, Chkalov Str., Kharkiv, Ukraine, 61000.

How to cite this article:

Zaitsev R.V., Kirichenko M.V., Khrypunov G.S., Zaitseva L.V., Chugai O.N., Drozdova A.A. Constructive solution of highly effective photoenergy module: development and experimental testing. Electrical engineering \& electromechanics, 2019, no.6, pp. 70-75. doi: 10.20998/2074-272X.2019.6.10. 